\title{
Infrastruktur dan Output Perkapita Antar Provinsi di Indonesia
}

\author{
Bayu Kharisma $^{1^{*}}$, Vita Nuraeiny ${ }^{2}$ \\ $1^{*}$ Departemen Ilmu Ekonomi, Fakultas Ekonomi dan Bisnis, Universitas Padjadjaran \\ 2 Lembaga Administrasi Negara (LAN) Jakarta
}

\section{Informasi Artikel \\ Sejarah artikel: \\ Diterima September 2018 \\ Disetujui Oktober 2018 \\ Dipublikasikan Oktober 2018}

\section{Keywords:}

Economic Growth,

Infrastructure

\begin{abstract}
A B S TR ACT
in 2010-2015, Indonesia's economic growth experienced a slowdown, the average economic growth of Indonesia during 2010-2015 was 5.65\%. Indonesia's economic growth was influenced by various conditions that developed in the world economy such as declining world commodity prices, high inflation after the price hike of subsidized fuels, and the decline in bank credit due to tightening monetary policy. The purpose of this study is to determine the effect of infrastructure which includes roads, electricity, clean water and ports on per capita output. This study uses a static and dynamic panel data model in 33 provinces in Indonesia during the period 2010-2015. The results of this study indicate that road and port infrastructure has a positive and significant influence on per capita output, while electricity and clean water infrastructure have a positive but insignificant influence. In this regard, the government can take a policy of increasing and building road infrastructure and improving service performance in the form of port loading and unloading productivity.
\end{abstract}




\section{Pendahuluan}

Pembangunan ekonomi pada suatu negara atau wilayah bertujuan untuk mencapai kemakmuran masyarakat melalui pertumbuhan ekonomi yang tinggi. Pertumbuhan ekonomi merupakan pertumbuhan output yang dibentuk oleh berbagai sektor ekonomi sehingga dapat menggambarkan kemajuan atau kemunduran yang telah dicapai sektor ekonomi tersebut pada suatu periode tertentu. Selain itu, pertumbuhan ekonomi juga menunjukkan sejauh mana aktivitas perekonomian akan menghasilkan tambahan pendapatan masyarakat pada suatu periode tertentu (Rahman dan Chamelia, 2015). Aktivitas perekonomian merupakan suatu proses penggunaan faktor-faktor produksi untuk menghasilkan output, maka proses ini akan menghasilkan suatu aliran balas jasa terhadap faktor produksi yang dimiliki oleh masyarakat (Mankiw, 2003). Indikator yang dapat digunakan sebagai tolak ukur tingkat kesejahteraan ekonomi masyarakat pada suatu negara atau wilayah adalah pendapatan perkapita.

Pendapatan perkapita merupakan ukuran yang digunakan untuk menggambarkan standar hidup (standard of living) suatu negara atau wilayah. Negara yang memiliki pendapatan perkapita tinggi umumnya memiliki standar hidup (standard of living) yang juga tinggi. Perbedaan pendapatan perkapita menggambarkan perbedaan kualitas hidup, negara kaya yang tercermin oleh pendapatan perkapita yang tinggi memiliki kualitas hidup yang lebih baik (angka harapan hidup, tingkat kesehatan, dan tingkat pendidikan) dibandingkan dengan negara miskin (Mankiw, 2006). Selain itu, pendapatan perkapita juga dapat digunakan untuk mengukur kinerja perekonomian suatu negara, melihat struktur perekonomian suatu negara, serta membandingkan kinerja perekonomian satu negara dengan negara-negara lain (Arsyad, 2010).
Pada tahun 2010-2015, pertumbuhan ekonomi Indonesia mengalami perlambatan, rata-rata pertumbuhan ekonomi Indonesia sepanjang tahun 20102015 sebesar 5,65\%. Bappenas (2014) menyatakan bahwa pertumbuhan ekonomi Indonesia dipengaruhi oleh berbagai kondisi yang berkembang dalam perekonomian dunia seperti menurunnya harga komoditas dunia, inflasi yang tinggi pasca kenaikan harga BBM bersubsidi, serta menurunnya kredit perbankan akibat pengetatan kebijakan moneter. Menurunnya harga komoditas dunia menyebabkan penurunan kinerja perdagangan luar negeri. Indonesia yang pada beberapa tahun terakhir mengandalkan ekspor sebagai salah satu sumber pertumbuhan yang penting turut terkena dampak dari penurunan kinerja perdagangan luar negeri akibat menurunnya harga komoditas dunia tersebut, dampak yang terjadi antara lain berupa perlambatan ekonomi di Indonesia. Secara agregat pertumbuhan ekonomi Indonesia pada tahun 2010-2015 mengalami perlambatan namun Produk Domestik Bruto (PDB) perkapita Indonesia menunjukkan tren positif kenaikan setiap tahunnya. PDB perkapita tahun 2010 adalah sebesar Rp 28.778.200 dan mengalami peningkatan sebanyak $22,18 \%$ pada tahun 2015 menjadi Rp 35.161.900. Gambar 1 menunjukkan pertumbuhan ekonomi dan PDB perkapita Indonesia pada tahun 2010-2015.

Kontribusi Produk Domestik Regional Bruto (PDRB) dalam membentuk Produk Domestik Bruto (PDB) yang dihasilkan oleh setiap wilayah di Indonesia masih belum menunjukkan pemerataan. Gambar 2. menunjukkan bahwa besaran kontribusi PDRB dari masing-masing wilayah atau daerah di Indonesia memiliki perbedaan yang cukup signifikan. Pulau Jawa memberikan kontribusi PDRB tertinggi sepanjang tahun 2010-2015 dengan persentase lebih dari $50 \%$, sementara kontribusi 


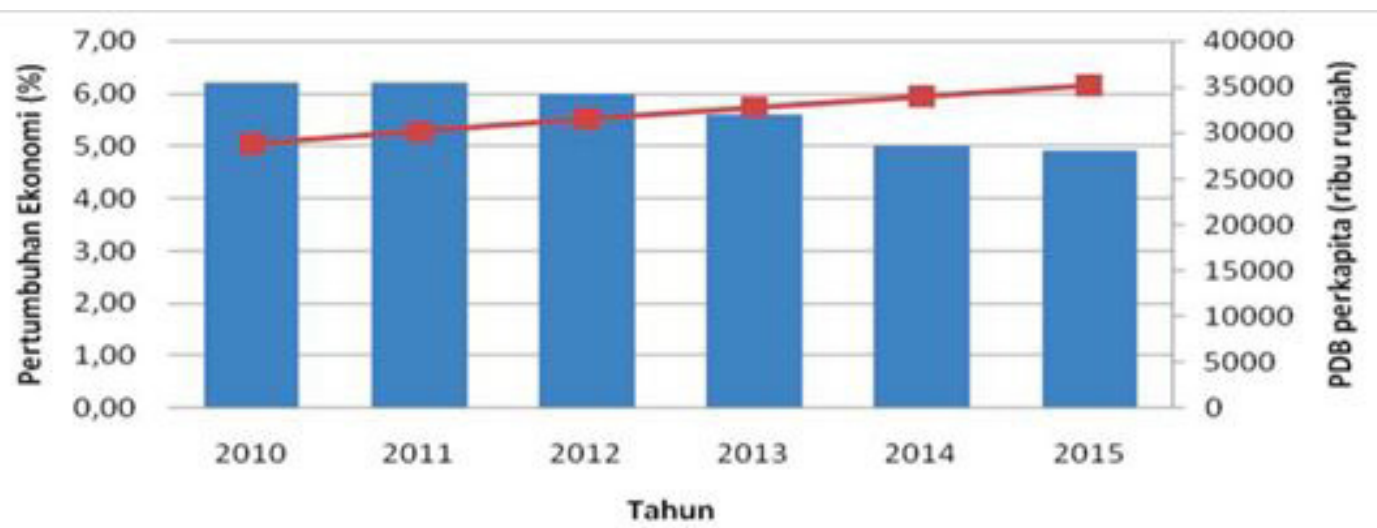

Pertumbuhan Ekonomi (\%) _- Produk Domestik Bruto per kapita (ribu rupiah)

Sumber : BPS, 2015

Gambar 1

Pertumbuhan Ekonomi dan PDB Perkapita Tahun 2010-2015

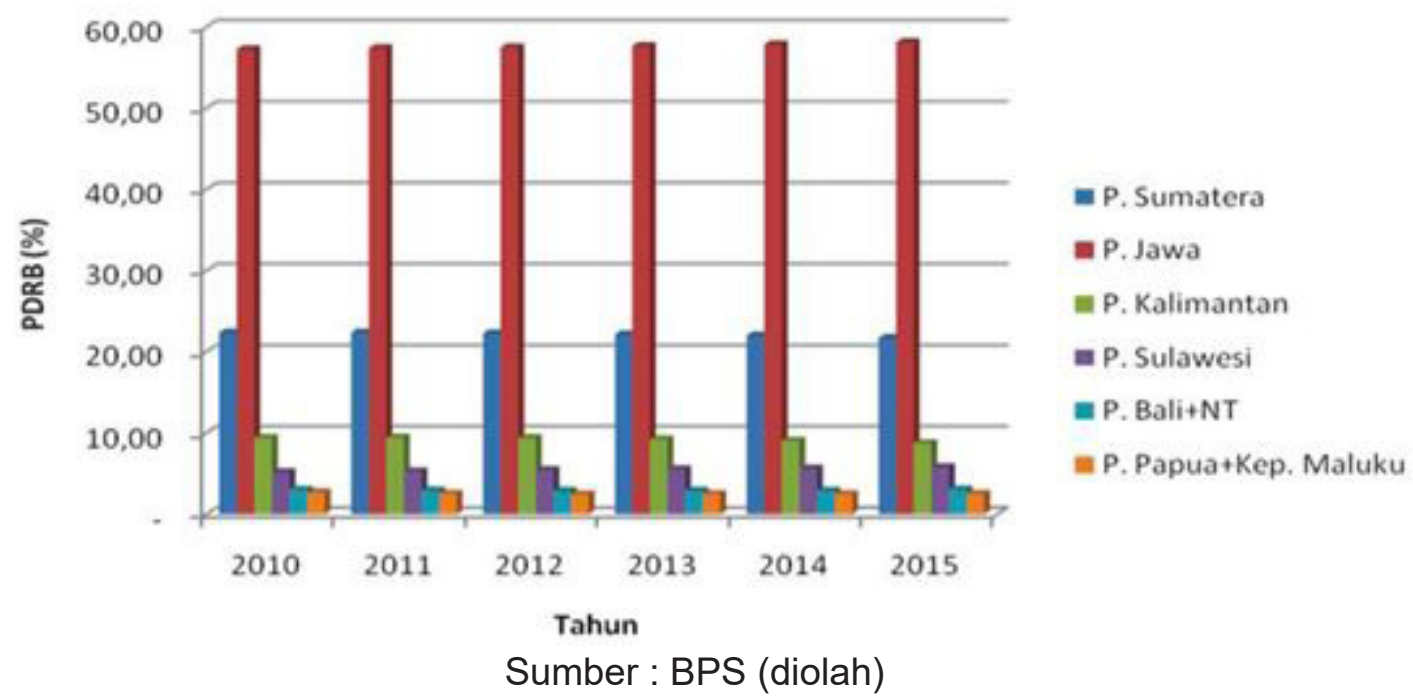

Gambar 2

Kontribusi PDRB Menurut Pulau di Indonesia Tahun 2010-2015

PDRB terendah terdapat pada Pulau Papua-Maluku dengan kontribusi berkisar pada angka $2 \%$.

Salah satu program pemerintah yang berupaya untuk meningkatkan pendapatan per kapita adalah Masterplan Percepatan dan Perluasan Pembangunan Ekonomi Indonesia (MP3EI). Melalui program ini diharapkan Indonesia mampu meningkatkan pendapatan perkapita dengan penyediaan infrastruktur yang mendukung aktivitas ekonomi. Menurut World Economic Forum 2015, infrastruktur menjadi salah satu sektor penting yang menentukan tingkat daya saing global Indonesia. Penilaian atas infrastruktur Indonesia terhadap Negara-negara Asia menempati peringkat 62 pada tahun 2015. Infrastruktur Singapura menempati urutan nomor 2, Malaysia dan Thailand secara berurutan menempati peringkat 24 dan 44 , sedangkan di bawah Indonesia adalah 
Filipina dan Vietnam.

Salah satu penyebab perbedaan kontribusi PDRB di Indonesia menurut Tambunan (2003) adalah keterbatasan transportasi. Peningkatan pada infrastruktur transportasi dapat menjadi salah satu alternatif dalam meningkatkan pemerataan kontribusi PDRB yang pada akhirnya akan meningkatkan pendapatan nasional, hal ini sesuai dengan penelitian Boopen (2006) yang menyatakan bahwa infrastruktur transportasi (jalan) telah memberikan kontribusi pada pendapatan nasional. Infrastruktur jalan mempunyai peran penting sebagai salah satu pendorong ekonomi. Jalan merupakan prasarana yang menghubungkan antara produsen, pasar dan konsumen. Ketersediaan infrastruktur jalan merupakan salah satu syarat pertumbuhan investasi dan industri karena efektivitas dan efisiensi kegiatan industri dipengaruhi oleh kondisi jalan, di sisi lain penyediaan infrastruktur jalan memiliki multiplier effect yang besar terhadap perekonomian karena melibatkan banyak sektor, mulai dari sektor yang berkaitan langsung terhadap penyediaan infrastruktur jalan maupun sektor yang tidak berkaitan namun mendapatkan manfaat dari adanya infrastruktur jalan. Tahun 2010 total panjang jalan sebesar $487.314 \mathrm{~km}$ dan mengalami peningkatan sebanyak 7,5\% menjadi $523.974 \mathrm{~km}$ pada tahun 2015. Total panjang jalan dalam kondisi baik sebesar $221.137 \mathrm{~km}$, keadaan sedang sebesar $122.093 \mathrm{~km}$, keadaan rusak $103.650 \mathrm{~km}$ dan dalam keadaan rusak berat sebesar $77.094 \mathrm{~km}$. Provinsi yang memiliki jalan berkondisi baik dan sedang tertinggi terdapat di Provinsi Jawa Timur sedangkan jalan berkondisi rusak dan rusak berat tertinggi berada di Provinsi Sumatera Utara (Kementerian PU dan PR, 2015).

Selain infrastruktur jalan, energi listrik merupakan hal penting yang dibutuhkan dalam aktivitas perekonomian. Pengelolaan listrik sebagian besar dilakukan oleh PT Perusahaan Listrik Negara
(PLN). Penjualan energi listrik di Indonesia terus meningkat pada tahun 2010-2015, yang berasal dari jumlah pelanggan rumah tangga, industri dan pemerintah. Penjualan energi listrik tahun 2010 adalah sebesar 147.297 GWh dan mengalami peningkatan sebanyak $37,7 \%$ pada tahun 2015 menjadi 202.846 GWh. Persentase energi listrik terjual terhadap total energi listrik terjual tertinggi terdapat di Provinsi Jawa Barat yakni sebesar $21,47 \%$ sedangkan yang terendah di Provinsi Sulawesi Barat sebesar $0,13 \%$ (BPS, 2015). Terkait dengan infrastruktur air bersih, pemerintah melalui Perusahaan Daerah Air Minum (PDAM) melakukan kegiatan pengadaan, penjernihan, penyediaan dan penyaluran air bersih kepada pelanggan rumah tangga, industri dan konsumen lainnya. Kapasitas produksi PDAM tahun 2010 sebesar 183.754 liter per detik mengalami peningkatan sebanyak $13,91 \%$ pada tahun 2015 menjadi 209.320 liter per detik. Persentase kapasitas produksi PDAM terhadap total kapasitasnya tertinggi pada tahun 2015 terdapat di Provinsi Jawa Timur yakni sebesar $13,99 \%$ sedangkan yang terendah di Provinsi Papua Barat sebesar 0,19\% (BPS, 2015). Pelabuhan juga melakukan peran penting dalam meningkatkan perekonomian masyarakat sebagai transportasi angkutan umum dan pengangkutan barang. Volume bongkar muat pelabuhan tahun 2010 sebesar 703.024.941 Ton mengalami peningkatan $46,44 \%$ pada tahun 2015 menjadi 1.029.504.406 Ton. Persentase volume bongkar muat terhadap total volume bongkar muat tertinggi pada tahun 2015 terdapat di Provinsi Kalimantan Timur yakni sebesar 29,26\% sedangkan yang terendah di Provinsi Gorontalo sebesar 0,11\% (BPS, 2015).

Friawan (2008) menyatakan bahwa ada tiga alasan utama mengapa infrastruktur penting dalam sebuah integrasi ekonomi. Alasan pertama adalah ketersediaan infrastruktur yang baru merupakan mesin utama pembangunan ekonomi. Kedua, un- 
tuk memperoleh manfaat yang penuh dari integrasi, ketersediaan jaringan infrastruktur sangat penting dalam memperlancar aktivitas perdagangan dan investasi. Ketiga, adalah perhatian terhadap perbaikan infrastruktur juga penting untuk mengatasi kesenjangan pembangunan ekonomi antar negara.

Penelitian mengenai pengaruh infrastruktur terhadap pertumbuhan ekonomi telah dilakukan pada beberapa negara. Mamatzakis (2008) menyatakan bahwa infrastruktur merupakan komponen penting dalam aktivitas ekonomi di Negara Yunani. Infrastruktur publik dapat mengurangi sebagian besar biaya pada industri manufaktur, karena infrastruktur publik dapat memperkuat pertumbuhan produktivitas sumber daya. Eshafani (2007), Aschauer (1989), Canning dan Pedroni (1999) juga melakukan penelitian tentang infrastruktur dengan hasil yang menyatakan bahwa terdapat pengaruh positif yang tinggi dari infrastruktur terhadap pertumbuhan ekonomi.

Sementara itu, penelitian terhadap infrastruktur yang dilakukan di Indonesia menunjukkan bahwa infrastruktur memberikan pengaruh terhadap pertumbuhan ekonomi. Setiadi (2006) meneliti kaitan infrastruktur dan pertumbuhan ekonomi di Pulau Sumatera dan menemukan bahwa setiap jenis infrastruktur (jalan, listrik dan telepon) secara signifikan memiliki pengaruh positif terhadap pertumbuhan output perekonomian daerah, meskipun masingmasing infrastruktur memberikan kontribusi yang berbeda. Amrullah (2006) juga melakukan penelitian tentang pengaruh pembangunan infrastruktur (jalan, listrik, telepon dan air bersih) terhadap pertumbuhan ekonomi regional di Indonesia untuk Pulau Jawa-Bali dan luar Pulau Jawa menghasilkan bahwa setiap jenis infrastruktur memiliki pengaruh yang signifikan terhadap output perkapita.

Menurut Basri dan Munandar (2009), tersedianya fasilitas infrastruk- tur akan merangsang pembangunan di suatu daerah atau negara. Semakin cepat dan besar pembangunan ekonomi yang hendak digerakkan maka semakin banyak fasilitas infrastruktur yang diperlukan. Tanpa ketersediaan infrastruktur yang memadai, dapat dipastikan suatu kegiatan ekonomi atau pembangunan akan berjalan tersendat. Bappenas (2003) menyatakan bahwa pembangunan infrastruktur dan pembangunan ekonomi mempunyai hubungan yang erat dan saling bergantung satu sama lain, sehingga perbaikan infrastruktur pada umumnya akan meningkatkan mobilitas faktor produksi terutama penduduk, memperlancar perdagangan antar daerah yang berasal dari mobilitas barang dan jasa serta dapat mengurangi disparitas harga barang. Sebagai penggerak perekonomian nasional keberadaan infrastruktur mutlak diperlukan, tanpa infrastruktur yang mencukupi dan berkualitas, perekonomian tidak dapat tumbuh seperti yang diharapkan. Oleh karena itu, tujuan penelitian ini adalah mengetahui pengaruh infrastruktur jalan, listrik, air bersih dan pelabuhan terhadap output perkapita dan kebijakan apa yang harus dilakukan oleh pemerintah melalui pembangunan infrastruktur dalam meningkatkan output perkapita.

\section{Metode}

Penelitian ini menggunakan data sekunder berupa data panel yang merupakan gabungan data time series dan cross section. Data time series pada periode 2010-2015 dimana dalam periode tersebut terdapat program pemerintah yaitu Masterplan Percepatan dan Perluasan Pembangunan Ekonomi Indonesia (MP3EI) dan Nawacita serta data cross section yaitu jumlah provinsi di Indonesia sebanyak 33 provinsi. Cakupan wilayah penelitian meliputi seluruh Indonesia dan untuk menjamin data seriesnya, data provinsi pemekaran digabungkan dengan provinsi induknya. 
Penelitian ini menggunakan data sekunder yang bersumber dari Badan Pusat Statistik, PLN, Kementerian ESDM dan Kementerian Pekerjaan Umum dan Perumahan Rakyat (Kementerian PU dan PR) serta instansi-instansi terkait. Data yang digunakan meliputi data PDRB perkapita $(R p)$, rata-rata lama sekolah (tahun), investasi (Rp), infrastruktur yang meliputi panjang jalan nasional $(\mathrm{km})$, energi listrik yang terjual (kwh), kapasitas produksi air bersih (liter per detik), volume bongkar muat barang pelabuhan (ton), dan rasio sektor pertanian (\%) serta rasio konsumsi pemerintah (\%).

Spesifikasi model yang digunakan diadaptasi dari beberapa penelitian sebelumnya dengan melakukan penyesuaian-penyesuaian yang dianggap akan memberikan hasil yang lebih baik untuk menjelaskan pengaruh infrastruktur terhadap output perkapita di Indonesia. Model yang digunakan merupakan modifikasi dari model penelitian Canning (1999) dan Maryaningsih et al (2014). Canning (1999) menyatakan bahwa output agregat bergantung pada input dan produktivitas dimana input ini digunakan; input bagi agregat produksi meliputi modal manusia, modal finansial dan modal infrastruktur fisik. Pendekatan model yang digunakan untuk mengestimasi penelitian ini merupakan pengembangan dari fungsi produksi Cobb-Douglass, yaitu:

$\mathrm{Y}_{\mathrm{it}}=\mathrm{A}_{\mathrm{it}} \mathrm{K}_{\mathrm{it}}^{\alpha} \mathrm{H}_{\mathrm{it}}^{\beta} \mathrm{X}_{\mathrm{it}}^{\gamma} \mathrm{L}_{\mathrm{it}}^{1-\alpha-\beta-\gamma}$

dimana $\mathrm{Y}$ adalah total output, A adalah total faktor produktivitas, $\mathrm{K}$ adalah modal finansial, $\mathrm{H}$ adalah modal manusia, $\mathrm{X}$ adalah modal infrastruktur, $L$ adalah tenaga kerja dan $U$ adalah kesalahan/error term. Simbol $i$ untuk mengindeks negara dan $t$ untuk mengindeks waktu. Modifikasi dari penelitian Canning (1999) pada persamaan (1) diperlukan mengingat ketersediaan data dari variabel operasional yang ada dalam penelitian tersebut tersedia di provinsi
Indonesia dan adanya penambahan variabel baru yang ingin diteliti. Perbedaan pada satuan variabel menjadikan data variabel baik independen maupun dependen ditransformasikan dalam bentuk logaritma natural (Ln). Adapun model persamaan dalam penelitian ini adalah sebagai berikut:

$\mathrm{Y}_{\mathrm{it}}=\beta_{0}+\beta_{1} \mathrm{Y}_{\mathrm{it}-1}+\beta_{2} \mathrm{X}_{\mathrm{it}}+\beta_{3}$ Investasiit + $\beta_{4}$ Sekolahit $+\beta_{5}$ Pertanianit $+\beta_{6}$ Pemerintah $_{\text {it }}+$ $\mu_{\text {it }}$

$Y_{\text {it }}$ adalah output perkapita ADHK 2010, $Y_{\text {it-1 }}$ yaitu lag output perkapita, Investasi $_{\text {it }}$ yaitu Investasi yang diukur melalui pembentukan modal tetap bruto (PMTB) per jumlah penduduk, sekolah adalah rata-rata lama sekolah menunjukkan human capital, pertanian adalah Rasio sektor pertanian terhadap PDRB, pemerintah adalah rasio konsumsi pemerintah terhadap PDRB. Sementara itu, X menunjukkan variabel infrastruktur yang meliputi panjang jalan nasional per jumlah penduduk, energi listrik yang terjual per jumlah penduduk, volume bongkar muat barang per jumlah penduduk, kapasitas produksi air bersih per jumlah penduduk, sedangkan $\mu_{\mathrm{it}}$ adalah error term.

Ukuran-ukuran infrastrukturyang digunakan dalam penelitian ini merujuk pada studi-studi terdahulu dengan beberapa penyesuaian. Infrastruktur jalan mengacu pada panjang jalan nasional $(\mathrm{km})$. Variabel panjang jalan digunakan dalam penelitian Canning (1999) dan Boopen (2006). Infrastruktur listrik menggunakan ukuran energi listrik yang terjual (Kwh). Penjualan energi listrik ini meliputi kelompok rumah tangga, bisnis dan lainnya (sosial, pemerintah dan penerangan jalan umum). Variabel energi listrik yang terjual (Kwh) digunakan dalam penelitian Prasetyo dan Firdaus (2009). Infrastruktur air bersih mengacu pada kapasitas produksi air bersih (liter per detik) dan digunakan dalam penelitian Amrullah (2006). Infrastruktur pelabuhan mengacu 
pada volume bongkar muat barang (ton). Ukuran volume bongkar muat barang ini sebelumnya digunakan dalam penelitian Maryaningsih et al (2014).

Variabel modal manusia (human capital) menggunakan indikator pendidikan yaitu rata-rata lama sekolah (tahun). Penelitian sebelumnya yang menggunakan rata-rata lama sekolah adalah Canning (1999) dan Serven (2011). Variabel investasi menggunakan indikator pembentukan modal tetap bruto riil (juta rupiah) yang digunakan Kodongo dan Ojah (2016) dan Maryaningsih et al (2014). Variabel rasio sektor pertanian terhadap PDRB (\%) serta variabel rasio konsumsi pemerintah terhadap PDRB (\%) juga digunakan pada penelitian sebelumnya yang dilakukan oleh Maryaningsih et al (2014). Variabel rasio sektor pertanian terhadap PDRB digunakan untuk melihat peranan sektor pertanian dalam perekonomian nasional diukur melalui kontribusinya terhadap output perkapita.

\section{Hasil dan Pembahasan}

Tabel 2 menunjukkan hasil estimasi model regresi yang bertujuan untuk membandingkan model mana yang terbaik dan akan digunakan untuk estimasi. Metode data panel dinamis System GMM menggunakan instrumen variabel tambahan berupa jumlah penduduk dan kepadatan penduduk yang juga digunakan dalam penelitian Kodongo dan Ojah (2016) dan Sahin et al (2014). Kodongo dan Ojah (2016) menyatakan bahwa penduduk sebagai instrumen variabel berasal dari teori yang menjelaskan adanya hubungan kuat antara penduduk dan pendapatan nasional serta infrastruktur. Data panel dinamis dengan sistem GMM menghasilkan estimator yang efisien dan konsisten untuk mengatasi masalah validitas instrumen dan meminimalkan risiko bias karena masalah endogenitas (Baltagi, 2005).

Simon dan Gobin dalam Kodongo dan Ojah (2016) menemukan hubungan positif antara kepadatan penduduk dengan pertumbuhan ekonomi dan menyimpulkan bahwa dalam jangka panjang, pertumbuhan penduduk berpengaruh positif terhadap pendapatan perkapita. Weinhold dan Reis (dalam Kodongo dan Ojah, 2016) menyatakan terdapat hubungan positif yang kuat antara infrastruktur dan penduduk perkotaan. Esfahani dan Ramírez juga menemukan hubungan positif antara pengembalian investasi infrastruktur bersih dan kepadatan penduduk. Tabel 2 dibawah ini merupakan hasil estimasi menggunakan pooled least square (PLS), fixed effect model (FEM), random effect model (REM) dan System GMM.

Nilai dari koefisien lag-PDRB perkapita yang kurang dari satu menunjukkan bahwa telah terjadi proses konvergensi pendapatan antar provinsi di Indonesia. Pada analisis konvergensi kondisional dengan menggunakan data panel dinamis system GMM menunjukkan bahwa koefisien sebesar 0,69 dan signifikan pada tingkat kepercayaan 95\%. Konvergensi pendapatan antar provinsi di Indonesia memiliki tingkat konvergensi sebesar $37 \%$. Hal ini menunjukkan bahwa kecepatan masing-masing daerah untuk mencapai kondisi steady state adalah sebesar $37 \%$ per tahun. Adapun waktu untuk menutup setengah kesenjangan awal atau half life of convergence adalah lebih dari 2 tahun. Penelitian mengenai konvergensi pendapatan telah dilakukan di Indonesia dan menunjukkan hasil bahwa terjadi konvergensi pendapatan antar provinsi di Indonesia. Kharisma dan Saleh (2013) menemukan bahwa kecepatan konvergensi pendapatan adalah sebesar $5,9 \%$ per tahun dan half life time adalah sebesar 12 tahun. Kecepatan konvergensi yang berbeda dari penelitian terdahulu dapat disebabkan oleh perbedaan pemilihan variabel yang digunakan dalam penelitian, periode penelitian dan unit analisis penelitian. 
Tabel 1

Hasil Estimasi

\begin{tabular}{|c|c|c|c|c|c|c|}
\hline \multirow{4}{*}{ Variabel } & \multicolumn{6}{|c|}{ Variabel tidak Bebas : Pendapatan Per kapita } \\
\hline & \multirow[b]{2}{*}{ PLS } & \multirow[b]{2}{*}{$\begin{array}{l}\text { Fixed } \\
\text { Effect }\end{array}$} & \multirow[b]{2}{*}{$\begin{array}{c}\text { Random } \\
\text { Effect }\end{array}$} & \multicolumn{3}{|c|}{ GMM-SYS } \\
\hline & & & & Penduduk & $\begin{array}{l}\text { Kepadatan } \\
\text { Penduduk }\end{array}$ & $\begin{array}{l}\text { Penduduk \& } \\
\text { Kepadatan } \\
\text { Penduduk }\end{array}$ \\
\hline & (1) & (2) & (3) & & (4) & \\
\hline $\mathrm{Y}_{\mathrm{it}-1}$ & $\begin{array}{c}0,944^{* \star \star} \\
(0,012)\end{array}$ & $\begin{array}{c}0,751^{\text {*** }} \\
(0,035)\end{array}$ & $\begin{array}{c}0,910^{* k \pi} \\
(0,015)\end{array}$ & $\begin{array}{c}0,694^{\text {*x* }} \\
(0,037)\end{array}$ & $\begin{array}{c}0,688^{* k+\pi} \\
(0,036)\end{array}$ & $\begin{array}{c}0,692^{\star * *} \\
(0,031)\end{array}$ \\
\hline Investasi & $\begin{array}{c}0,033^{* * \pi} \\
(0,009)\end{array}$ & $\begin{array}{l}0,070^{* * *} \\
(0,022)\end{array}$ & $0,053^{* \star \star x}$ & $0,058^{* x+}$ & $0,052^{\star *}$ & $0,049^{* * *}$ \\
\hline Rata-Rata Lama Sekolah & $\begin{array}{l}-0,003 \\
(0,003)\end{array}$ & $\begin{array}{l}0,022^{\star \star} \\
(0,009)\end{array}$ & $\begin{array}{l}-0,001 \\
(0,004)\end{array}$ & $\begin{array}{l}0,041^{\text {tx* }} \\
(0,010)\end{array}$ & $\begin{array}{l}(0,024) \\
0,044^{* * *} \\
(0,010)\end{array}$ & $\begin{array}{c}0,044^{\star * \pm} \\
(0,009)\end{array}$ \\
\hline Panjang Jalan Nasional & $\begin{array}{c}0,003 \\
(0,003)\end{array}$ & $\begin{array}{l}-0,002 \\
(0,007)\end{array}$ & $\begin{array}{l}0,008^{* *} \\
(0,004)\end{array}$ & $\begin{array}{l}0,011^{\star *} \\
(0,005)\end{array}$ & $\begin{array}{c}0,009^{*} \\
(0,005)\end{array}$ & $\begin{array}{c}0,010^{*} \\
(0,005)\end{array}$ \\
\hline Energi Listrik Terjual & $\begin{array}{c}0,017 \\
(0,008)\end{array}$ & $\begin{array}{c}0,009 \\
(0,010)\end{array}$ & $\begin{array}{c}0,015 \\
(0,009)\end{array}$ & $\begin{array}{c}0,009 \\
(0,009)\end{array}$ & $\begin{array}{c}0,011 \\
(0,007)\end{array}$ & $\begin{array}{c}0,012 \\
(0,007)\end{array}$ \\
\hline Kapasitas Produksi Air Bersih & $\begin{array}{c}0,002 \\
(0,004)\end{array}$ & $\begin{array}{c}0,003 \\
(0,003)\end{array}$ & $\begin{array}{c}0,001 \\
(0,004)\end{array}$ & $\begin{array}{c}0,001 \\
(0,003)\end{array}$ & $\begin{array}{c}0,001 \\
(0,003)\end{array}$ & $\begin{array}{c}0,001 \\
(0,003)\end{array}$ \\
\hline Volume Bongkar Muat Barang & $\begin{array}{c}0,001 \\
(0,002)\end{array}$ & $\begin{array}{c}0,001 \\
(0,002)\end{array}$ & $\begin{array}{c}0,002 \\
(0,002)\end{array}$ & $\begin{array}{c}0,005^{* \star \star} \\
(0,001)\end{array}$ & $\begin{array}{c}0,004^{* * *} \\
(0,001)\end{array}$ & $\begin{array}{c}0,005^{* * 2} \\
(0,001)\end{array}$ \\
\hline Konsumsi Pemerintah & $\begin{array}{l}-0,044 \\
(0,037)\end{array}$ & $\begin{array}{c}-0,471^{* * *} \\
(0,178)\end{array}$ & $\begin{array}{c}-0,113^{\star *} \\
(0,050)\end{array}$ & $\begin{array}{c}-0,773^{* t *} \\
(0,158)\end{array}$ & $\begin{array}{c}-0,820^{\text {*t* }} \\
(0,153)\end{array}$ & $\begin{array}{c}-0,817^{\star * x} \\
(0,150)\end{array}$ \\
\hline Sektor Pertanian & $\begin{array}{c}0,036 \\
(0,034)\end{array}$ & $\begin{array}{c}-0,803^{\star \star \star *} \\
(0,160)\end{array}$ & $\begin{array}{c}-0,047 \\
(0,046)\end{array}$ & $\begin{array}{c}-0,109^{* x *} \\
(0,177)\end{array}$ & $\begin{array}{c}-0,111^{\text {*** }} \\
(0,162)\end{array}$ & $\begin{array}{c}-0,111^{\star * *} \\
(0,154)\end{array}$ \\
\hline Cons & $\begin{array}{c}0,417 \\
(0,120) \\
\end{array}$ & $\begin{array}{c}0,318 \\
(0,481) \\
\end{array}$ & $\begin{array}{c}0,759 \\
(0,164) \\
\end{array}$ & $\begin{array}{c}0,436 \\
(0,628) \\
\end{array}$ & $\begin{array}{c}0,454 \\
(0,483) \\
\end{array}$ & $\begin{array}{c}0,451 \\
(0,470) \\
\end{array}$ \\
\hline R-Square & 0,933 & 0,942 & 0,908 & & & \\
\hline $\begin{array}{l}\operatorname{AR}(1) \\
\operatorname{AR}(2)\end{array}$ & & & & $\begin{array}{l}0,065 \\
0,968\end{array}$ & $\begin{array}{l}0,013 \\
0,962\end{array}$ & $\begin{array}{l}0,015 \\
0,957\end{array}$ \\
\hline Sargan Test & & & & 15,95 & 16,05 & 16,12 \\
\hline$\beta$-konvergen & & & & $36,58 \%$ & $37,45 \%$ & $36,77 \%$ \\
\hline The half-life konvergen & & & & 2 tahun & 2 tahun & 2 tahun \\
\hline
\end{tabular}

Infrastruktur jalan mempunyai pengaruh positif dan signifikan terhadap output perkapita dengan nilai koefisien sebesar 0,009. Artinya, bahwa setiap penambahan panjang jalan nasional sebesar $1 \%$ maka akan meningkatkan output perkapita sebesar $0,009 \%$ ceteris paribus. Hasil penelitian ini sesuai dengan hasil penelitian Amrullah (2006) dan Ahmad (2015) yang menyatakan bahwa jalan berpengaruh positif terhadap output perkapita. Selain itu, Calderon et al (2011) juga menyatakan bahwa infrastruktur berpengaruh terhadap tingkat produktivitas pekerja. Variabel infrastruktur yang paling berpengaruh adalah infrastruktur jalan dan kereta api.
Menurut Direktorat Jenderal Bina Marga (2014) bahwa sebanyak $82 \%$ logistik nasional masih menggunakan transportasi jalan darat. Oleh karena itu, jumlah kendaraan tidak dapat melebihi kinerja jalan. Semakin panjang jalan akan mengurangi kemacetan dan meningkatkan kinerja (Sanchez-Robles, 1998).

Infrastruktur listrik sekalipun memiliki hubungan positif, akan tetapi berdasarkan hasil regresi tidak berpengaruh signifikan terhadap nilai output perkapita. Hal ini sesuai dengan penelitian dari Suryanto (2013) bahwa sampai saat ini energi listrik yang terjual tidak berdampak secara signifikan terhadap output meng- 
ingat masih terbatasnya pemanfaatan dan tingkat layanan energi listrik. Tahun 2010 energi listrik yang terjual dilihat dari sisi pengguna paling besar dimanfaatkan oleh sektor rumah tangga dibandingkan dengan jenis pengguna lainnya sebesar $40,62 \%$ meningkat menjadi $43,72 \%$ dari total pengguna listrik pada tahun 2015, sedangkan sektor industri mengalami penurunan yang semula sebesar $34,61 \%$ menjadi $31,59 \%$ dari total pengguna. Energi listrik yang terjual dari sektor industri mengalami penurunan diduga akibat melemahnya aktivitas produksi (Bank Indonesia, 2015). Ketersediaan infrastruktur listrik di Indonesia juga tidak terdistribusi secara merata, terlihat dari energi listrik yang terjual berbeda antar provinsi di Indonesia. Terdapat beberapa provinsi yang memiliki energi listrik yang terjual perkapita rendah dan kurang dari rata-rata tingkat nasional yaitu Provinsi NTT (146,4 KWh) dan Provinsi Sulawesi Barat (201,8 KWh). Adam (2016) menyatakan bahwa Pulau Jawa memiliki tingkat ketersediaan energi listrik yang lebih tinggi dibandingkan dengan luar Pulau Jawa, karena Pulau Jawa memiliki populasi penduduk yang sangat tinggi serta konsentrasi industri di Pulau Jawa membuat tingkat penjualan energi listrik di pulau ini jauh lebih tinggi dibandingkan dengan di luar Pulau Jawa. Masih rendahnya ketersediaan listrik di luar Pulau Jawa akan mempersulit upaya pemerintah mendorong investasi dan kegiatan bisnis keluar Pulau Jawa.

Infrastruktur air bersih sekalipun memiliki hubungan positif, akan tetapi tidak berpengaruh signifikan terhadap output perkapita. Tahun 2013 terjadi penurunan produksi air bersih yang dihasilkan oleh PDAM pada beberapa provinsi di Indonesia relatif terhadap tahun 2010. Hal ini menunjukkan kurangnya kemampuan perusahaan air bersih dalam melakukan penyediaan air bersih bagi masyarakat. Penggunaan air bersih melalui PDAM banyak digunakan di perkotaan. Selain itu, sebagian besar masyarakat masih memperoleh air bersih tidak melalui institusi formal PDAM tetapi mereka mengusahakan sendiri melalui pompa, sumur, mata air atau membeli dari pedagang air.

Infrastruktur pelabuhan mempunyai pengaruh positif dan signifikan terhadap output perkapita dengan nilai koefisien sebesar 0,005. Artinya, bahwa setiap penambahan volume bongkar muat barang di pelabuhan sebesar $1 \%$ maka akan meningkatkan output perkapita sebesar $0,004 \%$ ceteris paribus. Hasil penelitian ini sesuai dengan hasil penelitian dari Maryaningsih et al (2014) bahwa infrastruktur pelabuhan berpengaruh terhadap PDRB perkapita. Wang \& Hong (2011) menyatakan bahwa infrastruktur transportasi darat dan transportasi air berpengaruh positif dan signifikan terhadap tingkat pertumbuhan GDP perkapita di China.

Rata-rata lama sekolah mempunyai pengaruh positif dan signifikan terhadap output perkapita dengan nilai koefisien sebesar 0,044. Artinya, bahwa setiap peningkatan rata-rata lama sekolah sebesar $1 \%$ maka akan meningkatkan output perkapita sebesar $0,044 \%$ ceteris paribus. Hasil penelitian ini sesuai dengan hasil penelitian dari Canning (1999) bahwa modal manusia yang diwakili oleh rata-rata lama sekolah berpengaruh positif dan signifikan terhadap output perpekerja. Wibisono (2001) menyatakan bahwa pembangunan manusia yang dimulai dari bidang pendidikan tidak hanya memiliki dampak langsung terhadap pertumbuhan ekonomi suatu wilayah, akan tetapi juga memiliki dampak tak langsung yaitu dapat menjaga tingkat pertumbuhan ekonomi secara berkelanjutan. Garcia dan Soelistianingsih dalam Kharisma dan Saleh (2013) menyatakan bahwa investasi sumber daya manusia, termasuk pendidikan merupakan cara penting dan efektif untuk meningkatkan pendapatan provinsi yang memiliki PDRB perkapita lebih rendah di Indonesia. Provinsi dengan PDRB 
perkapita rendah dan daerah pedesaan dapat tumbuh lebih cepat karena memiliki keunggulan tingkat pendidikan yang lebih baik. Todaro dan Smith (2009) menyatakan bahwa pendidikan merupakan input (masukan) bagi fungsi produksi agregat dalam peranannya sebagai komponen modal manusia. Pendidikan berperan penting dalam meningkatkan kemampuan untuk menyerap teknologi dan mengembangkan kapasitas bagi terwujudnya pertumbuhan ekonomi.

Investasi mempunyai pengaruh positif dan signifikan terhadap output perkapita dengan nilai koefisien sebesar 0,049. Artinya, bahwa setiap penambahan investasi sebesar $1 \%$ maka akan meningkatkan output perkapita sebesar $0,049 \%$ ceteris paribus. Hasil penelitian ini sesuai dengan penelitian Maryaningsih et al (2014) bahwa investasi yang diukur melalui pembentukan modal tetap bruto (PMTB) berpengaruh positif dan signifikan terhadap output perkapita. Salah satu faktor peningkatan jumlah investasi tahun 2015 adalah iklim investasi yang kondusif dilihat dari meningkatnya kepercayaan investor untuk menanamkan modal di Indonesia serta kemudahan dalam proses perizinan usaha. Penelitian ini sejalan dengan teori pertumbuhan Harrod Domar dalam Jhingan (2004) bahwa investasi memberikan peranan dalam proses pertumbuhan ekonomi, khususnya multiplier effect yang dimiliki investasi yaitu menciptakan pendapatan dan meningkatkan kapasitas produksi.

Rasio sektor pertanian mempunyai pengaruh negatif dan signifikan terhadap output perkapita dengan nilai koefisien sebesar 1,112. Artinya, bahwa setiap penurunan rasio sektor pertanian sebesar $1 \%$ maka akan meningkatkan output perkapita sebesar $1,112 \%$ ceteris paribus. Menurut teori perubahan struktural (structural change theory) bahwa dengan memusatkan perhatiannya pada mekanisme yang memungkinkan negara-negara untuk mentransformasikan struktur perekonomian dalam negeri dari pola perekonomian pertanian subsistem tradisional ke perekonomian yang lebih modern, serta memiliki sektor industri manufaktur yang lebih bervariasi dan sektor jasa-jasa yang tangguh. Aliran pendekatan perubahan struktural ini didukung oleh W. Arthur Lewis dan Hollis B. Chenery (dalam Todaro, 2009). Chenery dalam Kuncoro (1997) menyatakan bahwa sejalan dengan peningkatan pendapatan perkapita, perekonomian suatu negara akan bergeser dari yang semula mengandalkan sektor pertanian menuju ke sektor industri.

Produk Domestik Bruto (PDB) sektor pertanian pada tahun 2010-2015 secara nominal mengalami peningkatan. PDB sektor pertanian atas dasar harga berlaku tahun 2010 sebesar Rp 956.119,70 Milyar meningkat menjadi 1.555.207 Milyar atau mengalami peningkatan sebanyak $62,66 \%$ pada tahun 2015 , sedangkan PDB sektor pertanian atas dasar harga konstan tahun 2010 mengalami peningkatan sebesar $22,52 \%$ yang semula $R p$ 956.119,70 Milyar menjadi sebesar Rp 1.171.445,80 Milyar. PDB sektor pertanian atas dasar harga berlaku cenderung mengalami peningkatan sebesar $10,22 \%$ setiap tahun. Berdasarkan kontribusi sektor pertanian terhadap PDB mengalami kecenderungan menurun sepanjang tahun 2010-2015. Pada tahun 2010 kontribusi sektor pertanian terhadap PDB sebesar $13,93 \%$ menurun menjadi $13,04 \%$ pada tahun 2015, namun sektor pertanian memberikan kontribusi PDB terbesar ke-3 setelah sektor industri pengolahan dan sektor perdagangan. Kontribusi terbesar pada tahun 2015 yaitu sektor industri pengolahan sebesar $21,54 \%$, peringkat kedua adalah sektor perdagangan mencapai $13,44 \%$ dan peringkat ketiga sektor pertanian sebesar $13,04 \%$. Widyaningsih et al (2015) menyatakan bahwa strategi pembangunan ekonomi di daerah yang mengadopsi pembangunan di negara- 
negara maju yaitu meningkatkan pertumbuhan nominal PDRB sektor pertanian dan menurunkan kontribusi sektor pertanian terhadap PDRB. Arah koefisien yang negatif ini terkait dengan akses ke teknologi, wilayah yang bergantung pada sektor pertanian dalam perekonomiannya pada umumnya memiliki kesempatan yang lebih rendah untuk mendapatkan pengaruh positif dari teknologi baru apabila dibandingkan dengan wilayah yang menggantungkan perekonomiannya pada sektor industri yang relatif lebih dinamis (Maryaningsih et al, 2014).

Rasio konsumsi pemerintah mempunyai pengaruh negatif dan signifikan terhadap output perkapita dengan nilai koefisien sebesar 0,817. Artinya, bahwa setiap penurunan rasio konsumsi pemerintah sebesar 1\% maka akan meningkatkan output perkapita sebesar $0,817 \%$ ceteris paribus. Hasil penelitian ini sesuai dengan penelitian dari Maryaningsih et al (2014) yang menyatakan bahwa share konsumsi pemerintah mempunyai pengaruh negatif dan signifikan terhadap PDRB perkapita. Barro (1991) menyatakan bahwa pengeluaran konsumsi pemerintah mempunyai hubungan terbalik dengan pertumbuhan, sebaliknya investasi memiliki hubungan yang positif dengan pertumbuhan. Wibisono (2003) juga menyatakan bahwa semakin besar pengeluaran pemerintah yang tidak produktif, maka akan semakin besar tingkat pertumbuhan yang berkurang. Produk Domestik Bruto (PDB) menurut pengeluaran konsumsi pemerintah pada tahun 2010-2015 secara nominal mengalami peningkatan. PDB menurut pengeluaran konsumsi pemerintah atas dasar harga berlaku tahun 2010 sebesar Rp 618.177,99 Milyar meningkat menjadi 1.123.749,88 Milyar atau mengalami peningkatan sebanyak $81,78 \%$ pada tahun 2015 , sedangkan PDB menurut pengeluaran konsumsi pemerintah atas dasar harga konstan tahun 2010 mengalami peningkatan sebesar $25,43 \%$ yang semula Rp 618.177,99 Milyar menjadi sebesar Rp 775.397,99 Milyar. PDB menurut pengeluaran konsumsi pemerintah atas dasar harga berlaku cenderung mengalami peningkatan sebesar $12,71 \%$ setiap tahun. Berdasarkan kontribusi konsumsi pemerintah terhadap PDB mengalami fluktuatif sepanjang tahun 2010-2015. Pada tahun 2010 kontribusi konsumsi pemerintah terhadap PDB sebesar 9,01\% menurun menjadi $8,63 \%$ pada tahun 2015 . Kontribusi terbesar pada tahun 2015 yaitu pengeluaran konsumsi rumah tangga sebesar $54,35 \%$ dan peringkat kedua adalah pembentukan modal tetap domestik bruto mencapai $32,41 \%$.

\section{Kesimpulan}

Tujuan dari penelitian ini adalah pertama untuk mengetahui pengaruh dari infrastruktur yang meliputi jalan, listrik, air bersih dan pelabuhan terhadap output perkapita. Kedua, menganalisa kebijakan apa yang harus dilakukan pemerintah dalam hal pembangunan infrastruktur sehingga dapat meningkatkan output perkapita. Berdasarkan hasil estimasi model persamaan dapat disimpulkan bahwa Infrastruktur jalan dan pelabuhan mempunyai pengaruh positif dan signifikan terhadap output perkapita, sedangkan infrastruktur listrik dan air bersih mempunyai pengaruh yang positif namun tidak signifikan.

Selanjutnya, infrastruktur jalan dan pelabuhan memberikan pengaruh yang positif dan signifikan dalam meningkatkan output perkapita. Terkait dengan hal tersebut, pemerintah dapat mengambil kebijakan berupa peningkatan dan pembangunan infrastruktur jalan serta peningkatan kinerja pelayanan infrastruktur pelabuhan dalam bentuk produktivitas bongkar muat pelabuhan. Hal ini sesuai dengan program MP3EI dan Nawacita yang dicanangkan pemerintah saat ini sebagai arahan pengembangan kegiatan ekonomi utama terintegrasi untuk mendukung percepatan dan perluasan 
pembangunan ekonomi.

\section{Saran}

Pada penelitian berikutnya menggunakan kualitas infrastruktur atau indeks infrastruktur dan periode penelitian yang digunakan lebih panjang sehingga hasil penelitian akan lebih baik. Pemerintah dapat memberi perhatian terhadap pemerataan pembangunan dan pemeliharaan infrastruktur termasuk untuk daerah-daerah yang memiliki kondisi infrastruktur yang kurang memadai. Selain itu, pemerintah diharapkan dapat menciptakan iklim investasi yang kondusif melalui penetapan peraturan-peraturan, kebijakan perpajakan dan kemudahan perizinan dalam berinvestasi di Indonesia.

\section{Daftar Pustaka}

Adam, L. (2016). Dinamika Sektor Kelistrikan di Indonesia:Kebutuhan dan Performa Penyediaan. Jurnal Ekonomi dan Pembangunan Vol. 24, No. 1

Ahmad, RM. (2015). Analisis Pengaruh Infrastruktur, Modal Manusia dan Modal Finansial terhadap Output Perkapita Kabupaten/Kota di Jawa Tengah. Tesis. Bandung:FEB Unpad

Amrullah, T. (2006). Analisis Pengaruh Pembangunan Infrastruktur terhadap Pertumbuhan Ekonomi Regional di Indonesia. Tesis. Jakarta:FE UI

Arsyad, L. (2010). Ekonomi Pembangunan Edisi 5. Yogyakarta:UPP STIM YKPN

Aschauer, D.A. (1989). Is Public Expenditure Productive? Journal of Monetary Economics 23, 177-200

Baltagi, B.H. (2005). Econometric Analysis of Panel Data. Third Edition. John Wiley \& Son Ltd, England

Bank Indonesia. (2015). Laporan Perekonomian Indonesia 2015. diakses 11 September 2017. http://www.bi.go.id
Bappenas. (2003). Kajian Pengembangan Lembaga Keuangan dan Investasi Infrastruktur. Direktorat Pengembangan Kelembagaan Prasarana Publik pada Deputi Bidang Sarana dan Prasarana. Jakarta

Bappenas. (2014). Rencana Pembangunan Jangka Menengah 2015-2019

Barro, RJ \& Sala-i-Martin, X. (1991). Economic Growth and Convergence Across the United States. Working Paper 3419. Cambridge, Mass: National Bureau of Economic Research

Basri, F. \& Munandar, H. (2009). Lanskap Ekonomi Indonesia : Kajian dan Renungan terhadap Masalah-Masalah Struktural, Transformasi Baru, dan Prospek Perekonomian Indonesia. Jakarta:Kencana

Boopen, S. (2006). Transport Infrastructure and Economic Growth:Evidence from Africa Using Dynamic Panel Estimates. The Empirical Economics Letters, 5(1):Januari 2006

Badan Pusat Statistik. (2015).Statistik Indonesia 2011-2016. diakses 11 September 2017. http://bps.go.id

Calderon, C. Moral-Benito E. \& Serven, L. (2011) Is Infrastructure Capital Productive? A Dynamic Heterogeneous Approach. World Bank. Policy Research Working Paper No. 5682

Canning,D (1999). Infrastructure's Contribution to Aggregate Output. World Bank. Policy Research Works Paper No. 2246

Canning, D. \& Pedroni, P. (1999) Infrastructure and Long Run Economic Growth. Consulting Assistance on Economic Reform II.Discussion Paper 57

Esfahani, H.S. \& Ramirez, M.T. (2003). Institutions, Infrastructure and Economic Growth. Journal of Development Economic, 70. 443-477. 
Friawan, D. (2008). Kondisi Pembangunan Infrastruktur di Indonesia. CSIS Vol.37. No.2 Juni 2008, Jakarta: Lembaga Penerbit Fakultas Ekonomi Universitas Indonesia

Jhingan, ML. (2004). Ekonomi Pembangunan dan Perencanaan, Jakarta: PT Raja Grafindo Persada

Kharisma, B. \& Saleh, S. (2013). Convergence of Income Among Provinces in Indonesia, 1984-2008: A Panel Data Approach. Journal of Indonesian Economy and Business Volume 28. Number 2. 167-190

Kodongo, O. \& Ojah, K. (2016). Does Infrastructure Really Explain Economic Growth in Sub-Saharan Africa? Review of Development Finance 6. 105-125

Kuncoro, M. (1997). Ekonomi Pembangunan. Teori, Masalah dan Kebijakan. Yogyakarta:UPP AMP YKPN

Mamatzakis, E.C. (2008). Economic Performance and Public Infrastructure: an Application to Greek Manufacturing. Bulletin of Economic Research 60. 307-326

Mankiw, N. G. (2003). Teori Makroekonomi. Edisi Kelima. Jakarta:Erlangga

Mankiw, N. G. (2006). Teori Makroekonomi Edisi Keenam. Jakarta:Erlangga

Maryaningsih, N. Hermansyah, O. \& Savitri, M. (2014), Pengaruh Infrastruktur terhadap Pertumbuhan Ekonomi Indonesia, Buletin Ekonomi Moneter dan Perbankan

Prasetyo, RB \& Firdaus, M. (2009). Pengaruh Infrastruktur pada Pertumbuhan Ekonomi Wilayah di Indonesia. Jurnal Ekonomi dan Kebijakan Pembangunan, 2(2):222-236.

Rahman, Y.A. \& Chamelia, A.L. (2015). Faktor-faktor yang Mempengaruhi PDRB Kabupaten/Kota Jawa Tengah
Tahun 2008-2012. Journal of Economics and Policy. Jejak 8 (1) (2015):88-99.

Sahin, O. Can, N. \& Demirbas, E. (2014). The Effects of Infrastructure Determinants on Economic Growth:European Union Sample. Eurasian Journal of Business and Economics, 7 (13), 11-27

Sanchez-Robles, B. (1998). Infrastructure Investment And Growth: Some Empirical Evidence, Contemporary Economic Policy. Western Economic Association International, vol.16(1), pages 98$108,01$.

Setiadi, E. (2006). Pengaruh Pembangunan Infrastruktur Dasar terhadap Pertumbuhan Ekonomi Regional Indonesia (8 Provinsi Di Sumatera). Tesis. Jakarta:FEUI

Suryanto, Y. (2013). Konsumsi Energi Listrik dan Pertumbuhan Ekonomi di Indonesia: Aplikasi dan Model, Majalah.indd. Edisi 03/Tahun XIX/2013. Spread 10 of 44 , Page $(10,79)$

Tambunan, TTH. (2003). Perekonomian Indonesia. Jakarta:Ghalia Indonesia

Todaro, M.P. \& Smith, S.C. (2000). Economics Development. 11th ed. Addison Wesley Longman,inc. Boston

Wang, C \& Hong. (2011) Transport Infrastructure and Regional Economic Growth : Evidence from China. University of International Business and Economics, Beijing.

Wibisono, Yusuf. (2001). Determinan Pertumbuhan Ekonomi Regional:Studi Empiris antar Propinsi di Indonesia. Jurnal Ekonomi dan Pembangunan Indonesia. Vol.1 No.2

(2003). Konvergensi di Indonesia Beberapa Temuan Awal dan Implikasinya, Ekonomi Dan Keuangan Indonesia, Vol. 51 No. 1

WEF. (2016). The Global Competitiveness 
Bayu Kharisma, dkk. MediaTrend 13 (2) 2018 p.277-290

Report 2011-2016. diakses 11 Sep-

tember 2017. https://www.weforum.org

Undang-Undang Nomor 38 Tahun 2004

tentang Jalan 